Marek A. KSIĄŻEK ${ }^{*}$, Janusz TARNOWSKI*

\title{
ESTIMATION OF TRANSMISSION \\ OF HAND PRESSURE FORCE THROUGH HUMAN BODY - EXPERIMENTAL INVESTIGATIONS
}

\begin{abstract}
SUMMARY
The experiments described in this article are part of the research leading to the development of a model, in which the man working with hand held percussive tool constitutes an active element of the system. Research had on purpose description of transmission of hand pressure force from hand tool, through human body to operator legs. During a new series of experiments, human operators stood on a horizontal platform and by exerting pressure on a tool's handle compared force realized by him with the sudden reference force. The human operator was considered as alive active element able to control the hand tool by exerting suitable pressure on the tool's handle to fulfill the task a priori defined.

The used test stand allowed for the generation of reference force, measurement and visualization of the reference, and realized forces on the monitor's screen. Several variants of the experiments were registered and analyzed. Special attention was paid to transient and steady states of human reactions subjected to vibration excitation perturbations coming from the tool with chosen frequencies. Simultaneous recordings of exerting pressure force on a tool's handle and platform horizontal reaction allowed visualization of force transmission through the human body between hands and legs for the investigated participants in transient and steady, after realized control, states. As results of the studies functions describing the transmission of vibrations through the human body were received.
\end{abstract}

Keywords: model of man-hand tool percussive system, vibration isolation of tool

\begin{abstract}
PRZENOSZENIE SIEY DOCISKU RĘKOJEŚCI PRZEZ CIALO OPERATORA - BADANIA EKSPERYMENTALNE
Eksperymenty opisane $w$ artykule stanowiq część badań prowadzacych do opracowania modelu, $w$ którym czlowiek pracujacy narzędziem ręcznym stanowi aktywny element uktadu. Badania miaty na celu opis transferu sity nacisku na narzędzie poprzez ciało ludzkie do nóg. Podczas nowych serii prowadzonych doświadczeń człowiek operator $w$ pozycji stojqcej miat za zadanie sterować narzędziem ręcznym w celu wykonania zadanego w pewnej chwili sygnatu skokowego - nacisku na rękojeść - petniqc rolę swoistego regulatora. Zbudowane stanowisko badawcze umożliwialo generacje sity referencyjnej oraz wizualizacje sity referencyjnej i realizowanej przez operatora. Zarejestrowano i zanalizowano kilka wariantów eksperymentu. Szczególnq uwage poświęcono reakcjom przejściowym i ustalonym czlowieka przy uwzględnieniu zaburzeń pochodzacych od narzędzia przy wybranych częstotliwościach. Jednoczesny pomiar sity nacisku na rękojeść i sity reakcji pomiędzy platforma, na której stat operator, i rama stanowiska pozwolit na wizualizacje przejścia sygnatu sity poprzez aktywne ciało operatora pomiędzy rękami a nogami badanych operatorów zarówno w stanie nieustalonym - podczas regulacji, jak i po zrealizowaniu regulacji. $W$ wyniku badań otrzymano otrzymano funkcje transmitancji opisujaca transmisje drgań przez ciato czlowieka.
\end{abstract}

Stowa kluczowe: model układu człowiek-ręczne narzędzie udarowe, wibroizolacja narzędzia

\section{INTRODUCTION}

Presented in this article measurements are a continuation of a test series of experiments published in (Basista et al. 2008, 2009, 2010, Książek et al. 2008, Książek and Tarnowski 2010), designed to search for a model of human operatormanual percussive tool system taking into account the human being as part of the system modeled. Research had on purpose a description of the transmission of hand pressure force from a hand tool, through a human body to operator legs. During a new series of experiments, a human operator stood on a platform and by exerting pressure on a tool's handle compared the force realized by him with the sudden reference force. The human operator was considered as an alive active element able to control a hand tool by exerting suitable pressure on a tool's handle to fulfill a task a priori defined.

The test stand shown in Figure 1 allows for the generation of reference force, measurement and visualization of the reference and realized forces on the monitor's screen.

Several variants of the experiments were registered and analyzed. Special attention was paid to transient and steady states of human reactions subjected to vibration excitation perturbations coming from the tool with chosen, controlled frequencies. Simultaneous recordings of exerting pressure force on a tool's handle and platform horizontal reaction

\footnotetext{
* Cracow University of Technology, Institut of Applied Mechanics, Krakow, Poland; książek@mech.pk.edu.pl, jantarno@mech.pk.edu.pl
} 
allowed for the visualization of force transition through a human body between hand and legs for the investigated participants.

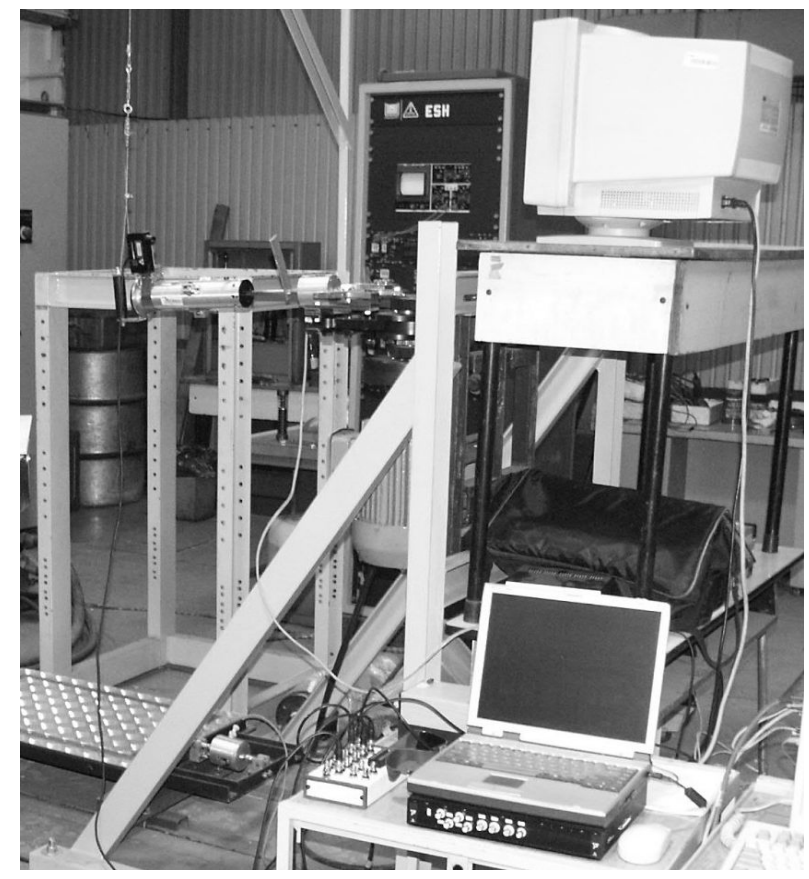

Fig. 1. View of test stand

\section{EXPERIMENTAL STUDIES}

In experimental investigations several volunteers took part. They executed sequentially planned steps of test procedure under the influence of simulated tool's vibrations with frequencies 5, 7, 9, 11, 13, 15, 17, 19 [Hz], with and without an isolated handle. During the tests operators stood on the mobile platform in the established position of the body, keeping the tool with one hand and observing force indicators on the monitor's screen as shown in Figures 2 and 3.

The pressure force on the tool's handle realized by the operator and the reaction force between the mobile platform and the immobile frame measured by strain gauges were simultaneously registered with a computer-generated step signal. This computer-generated signal was converted into analog form and was then routed to the analog output data acquisition card. Measurements, generation of given signals and visualization were performed in the LabView environment (National Instruments). Used data acquisition DaQCard NI 6024, NI SC 4345 conditioner, strain gauges amplifiers, and a measuring computer. The frequency of the vibration of the working tool was always determined by means of a motor controlled inverter inductor.

Recorded for all the tests the time histories of measured quantities were then subjected to processing in a computer software environment 2.2.7.8 D-Plot (HydeSoft USA). This step enabled the calibration and filtering recorded waveforms. As a result, we obtained time courses available for further analysis. Figures 4 and 5 show exemplary timings for the movement of the tool equal to 15 frequency [Hz] Figure 4 and to frequency $19[\mathrm{~Hz}]$ Figure 5, respectively. These drawings show waveforms of three forces: - given, realized by the operator pressure to handle, and horizontal reaction forces measured between platform and frame. This force is due to the transfer of force staged by the pressure of the vibrating tool handle by the operator's body. One can notice the difference between the force realized by the pressure and the strength of the reaction. Body clearly filtered pulses of pressure force on the tool.

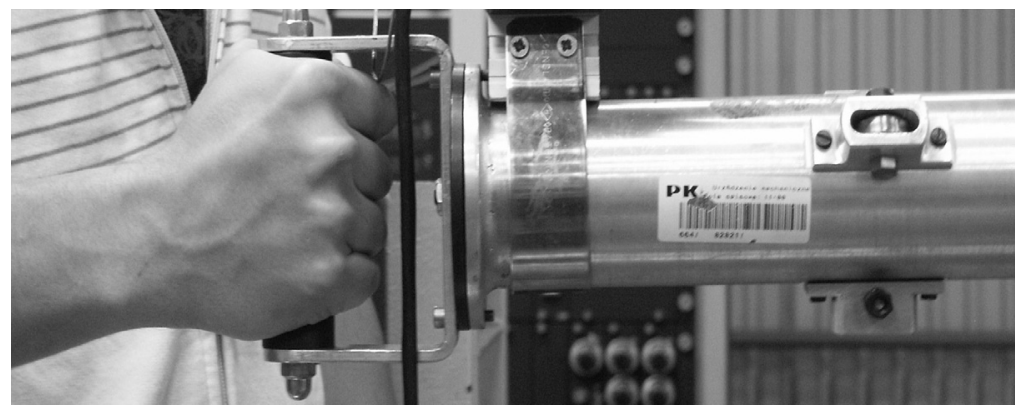

Fig. 2. Operator position during testing (hand)

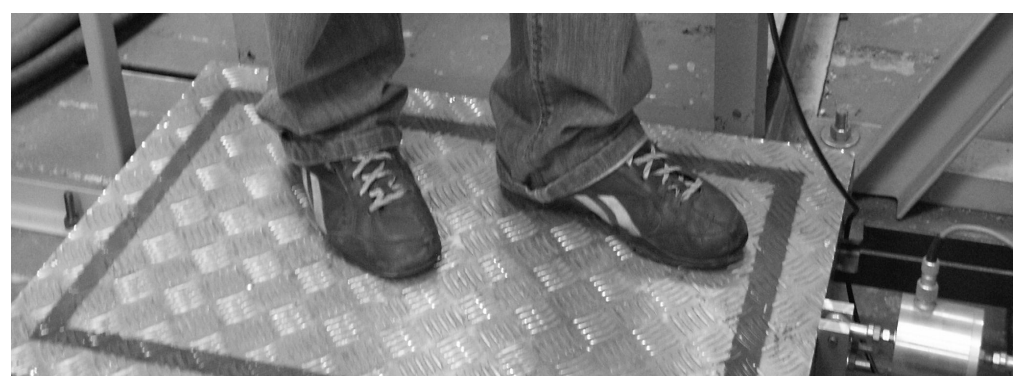

Fig. 3. Operator position during testing (legs) 


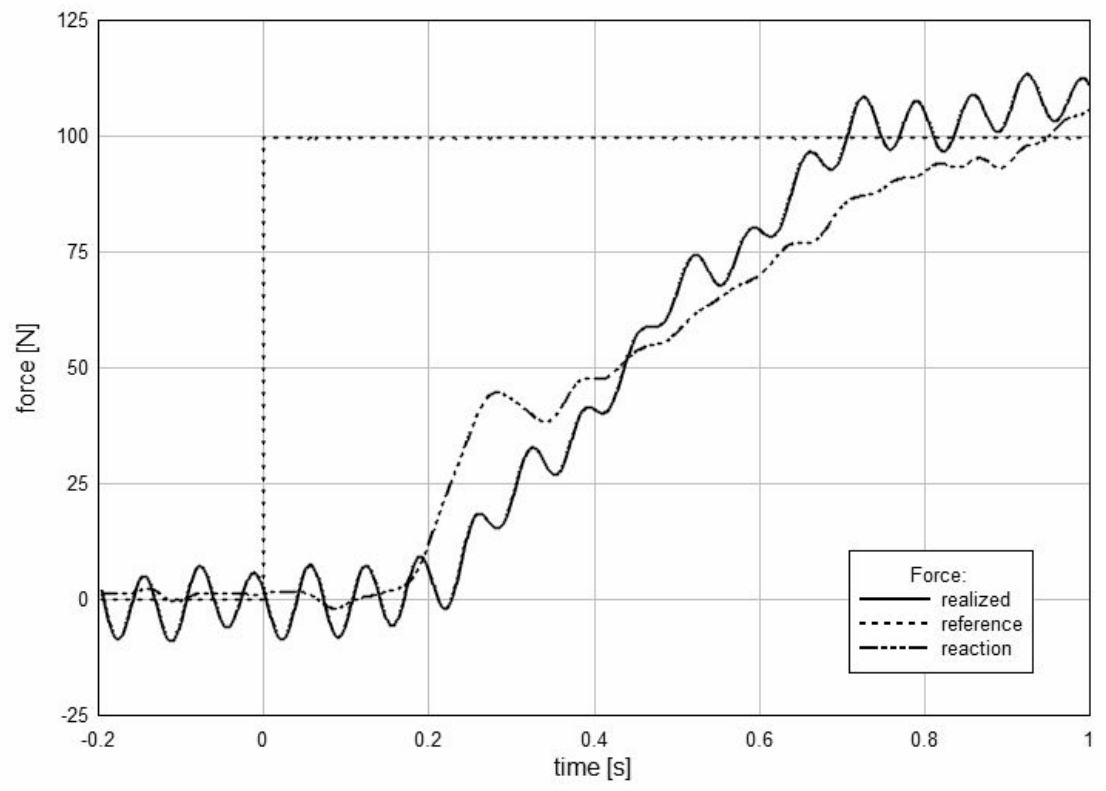

Fig. 4. Example of time course of forces $(15[\mathrm{~Hz}])$

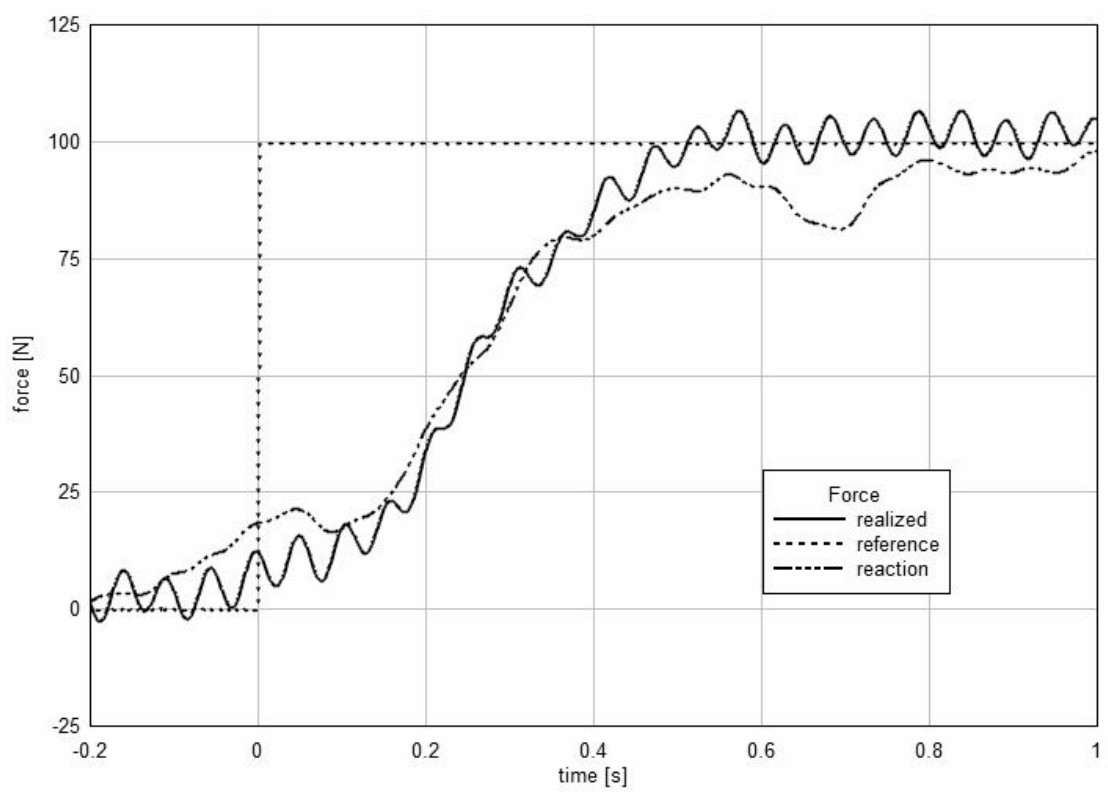

Fig. 5. Example of time course of forces $(19[\mathrm{~Hz}])$

\section{ANALYSIS OF THE RESULTS OF EXPERIMENTS}

The analysis of time-courses was performed also by computer in the software environment 2.2.7.8 D-Plot (HydeSoft USA). The analysis was focused on two problems:

1) estimation of the dynamic force between the handle and a tool and its dependence from isolation and frequency of movement of the toll,

2) an estimation of the transfer coefficient describing the force transmission through the operator's body.

The resulting timing forces exerted by the operator on the handle allowed the measurement of dynamic force for all tested frequency movements of the tool. Figure 6 shows the results of the measurements of the maximum dynamic force from the applied vibration isolation compared to the measurement without vibration isolation.

Analyzing power transmission through the body of the operator, a dynamic factor of moving force in the horizontal direction was estimated. The method of analysis was illustrated in Figure 7. It shows calculated values of the moving average force carried out by the pressure and compared with the measured force of the reaction. Dynamic coefficient of force transmission has been found as the ratio of the measured reaction force between the platform and frame measuring the force of the measured averaged pressure realized by the operator on the vibrating tool. 


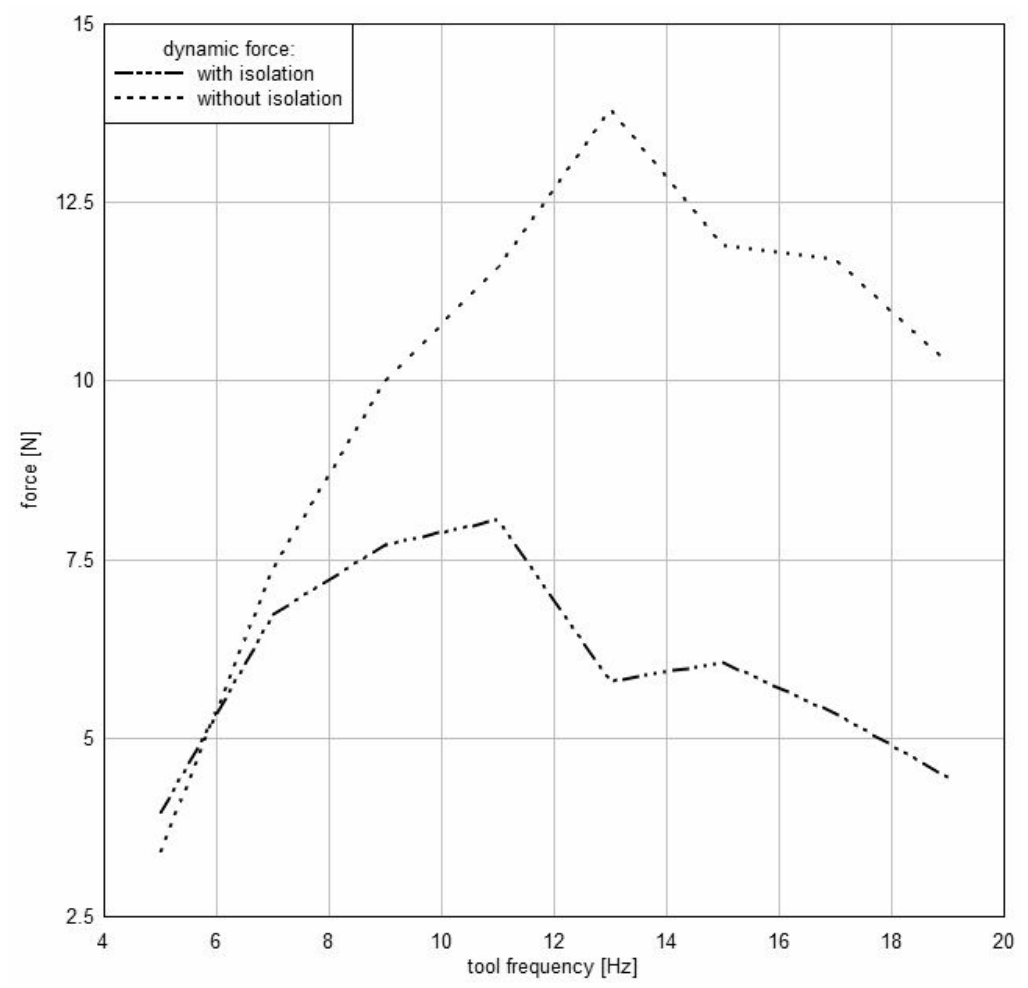

Fig. 6. The values of dynamic force for various frequencies of the tool's motion

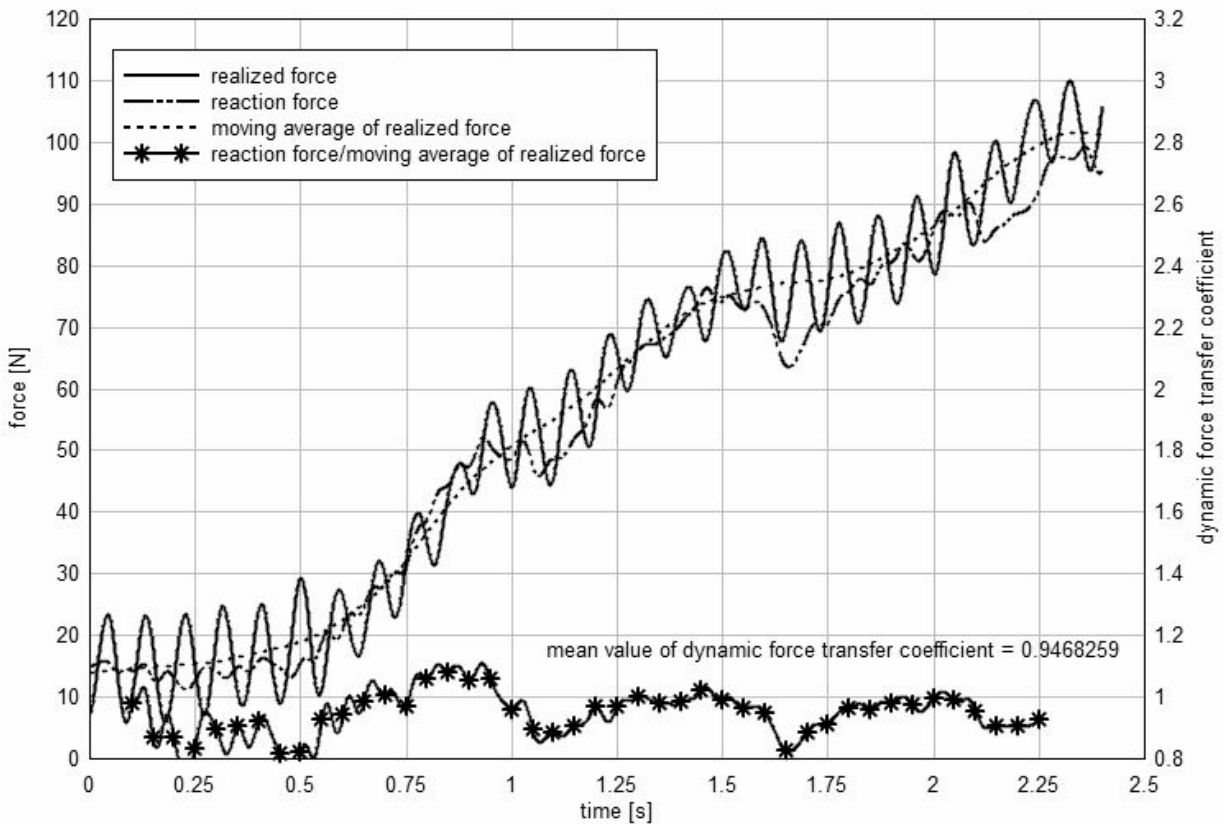

Fig. 7. Analysis of the transfer of pressure force to the handle

This coefficient varied during each test done, so to express it with one number for each sample were calculated their average value. These values were tabulated by grouping them according to excitation frequency for all tests performed by different operators with vibration isolation and without vibration isolation. Then, calculating the median value of the coefficient of the test frequency for all analyzed movements of the tool. The described analysis was repeated after isolation of the tests performed in the steady state.
The results of the analysis presents the following Figures 8 (for the full sample) and 9 (for the steady-state). During the analysis it was observed that a variable sinusoidal signal transmission of force by the working tool of the human body shows its effects similar to those of a low pass filter. The analysis of the measured signal frequency response between the platform and the frame has confirmed this observation - components with excitation frequencies were virtually absent in the spectrum of responses. 


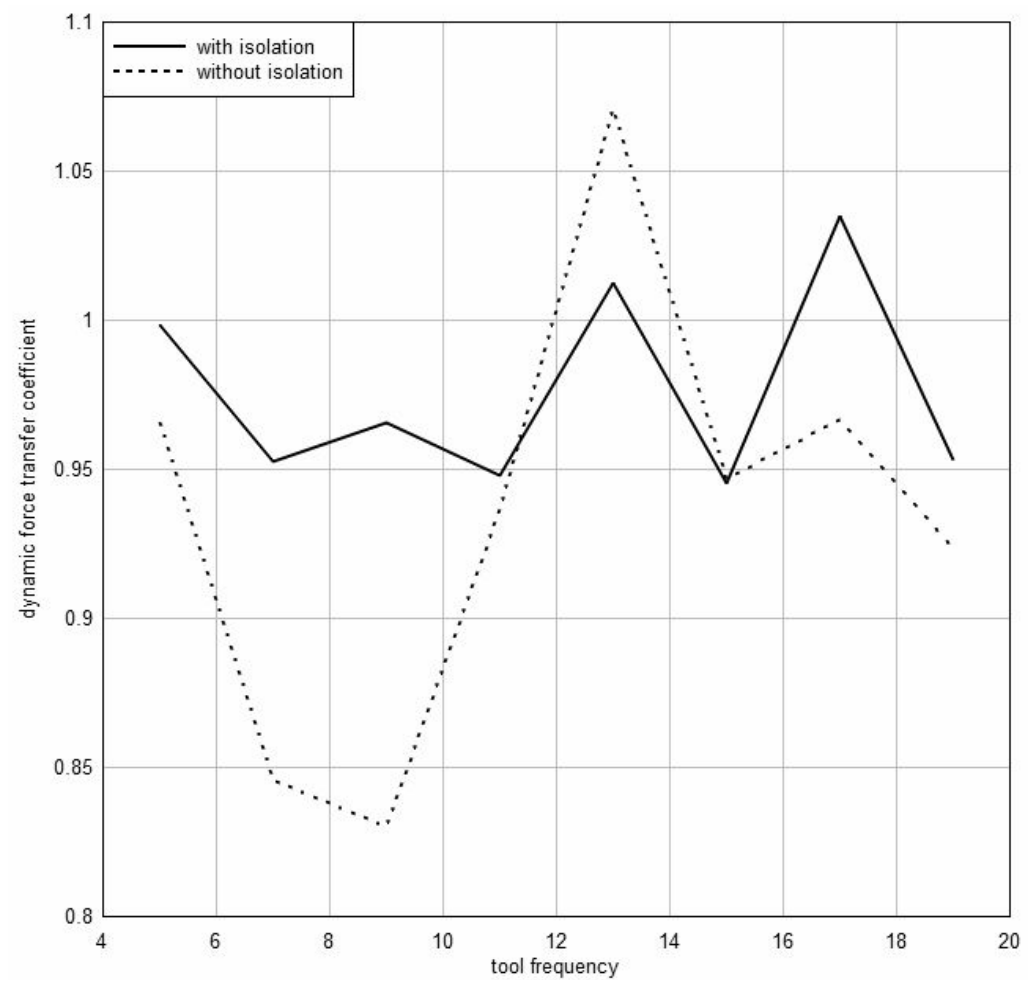

Fig. 8. Median dynamic transmission rate for various frequencies during the movement of the tool

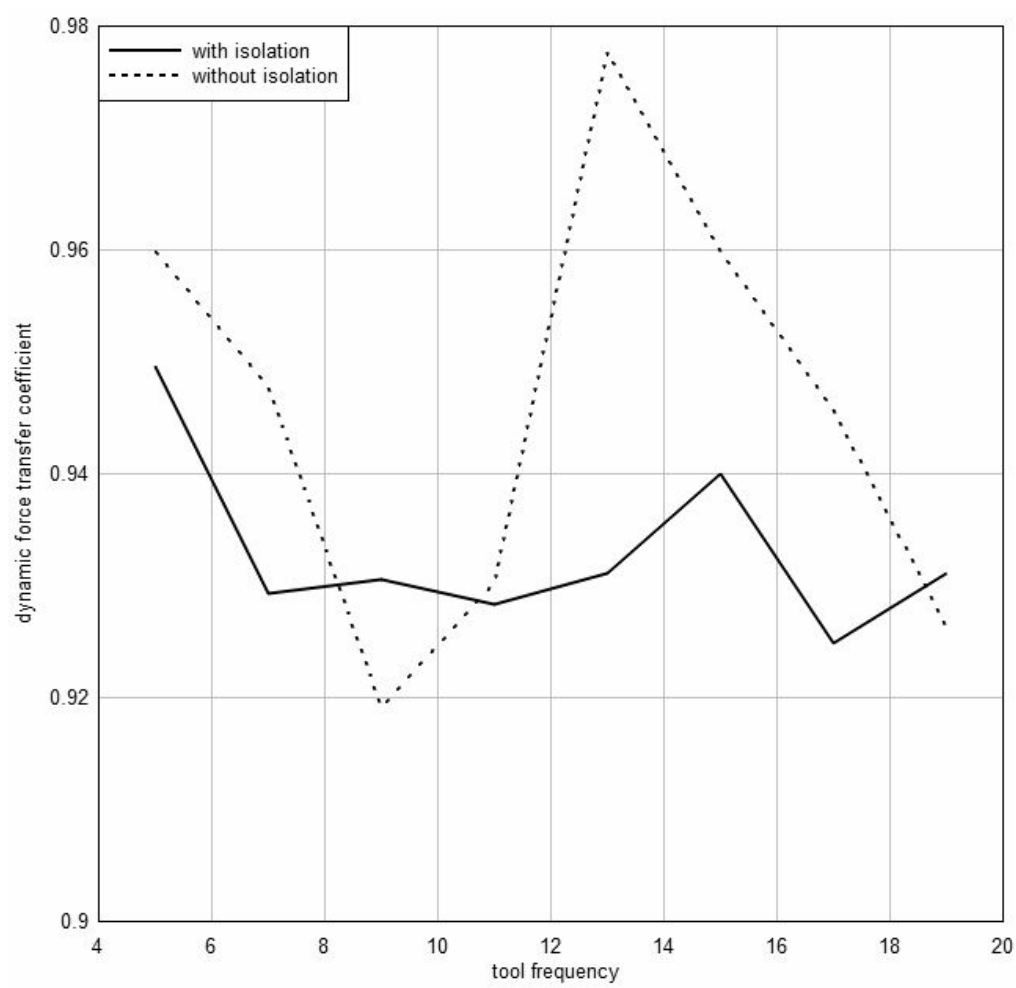

Fig. 9. Median dynamic transmission coefficient for various frequencies of steady-state tool motion

\section{CONCLUSIONS}

An analysis of the results of measurements of the dynamic component of force exerted by the operator on the tool during the control process (Fig. 5) may lead to the following conclusions:
- dynamic force varies with the frequency of a tool's motion,

- not achieved the expected continued growth dynamic force with increasing frequency instrument,

- the highest values of dynamic force were measured for the frequency $13[\mathrm{~Hz}]$ with vibration isolation and for $15[\mathrm{~Hz}]$ without vibration isolation. 
The results of the analysis of the transition signal strength clamp tool implemented by the operator confirms the action of the operator's body as a low pass filter. Dynamic transmission coefficient exceeds the value 0.9 . In the transient state, when a person performs the task actively the coefficient, for certain frequencies of movement of the tool exceeds the value 1.0. Vibration isolation of almost the entire frequency range covered by the tests carried out reduces the dynamic coefficient of transmission. The calculated average values may indicate a transfer of dependence on the frequency of the signal force of motion of tools. Tests must be done, however, be regarded as a test and to obtain full results repeat them by extending the frequency range of the tools and the number of participants.

\section{References}

Basista Z., Książek M.A., Tarnowski J. 2008, Testowe badania doświadczalne reakcji czlowieka - operatora narzedzia recznego przy sinusoidalnym sygnale wejściowym, Czasopismo Techniczne Mechanika Z1-M/2008, z. 1 (105), Kraków, 2008, pp. 27-36.

Basista Z., Książek M., Tarnowski J. 2009, Experimental investigations of human-operator as a pressure force regulator in man-hand tool system, Archives of Control Sciences, vol. 19(LIV), No. 1/2009, Polish Academy of Sciences, Committee of Automatic Control and Robotics, ISSN 0004-072X, pp. 81-92.

Basista Z., Ksiażek M.A., Tarnowski J. 2010, Investigations of Influence of Vibration on Human-Operator Control Functions, "Mechanics and control", Quarterly, vol. 29, No. 1, ISSN 1734-8927, pp. 1-5

Książek M.A., Tarnowski J. 2010, Wpływ amplitudy wibracji narzędzia ręcznego oraz struktury uktadu wibroizolacji na proces sterowania narzedziem - badania doświadczalne, Sympozium ,Wpływ wibracji na otoczenie", Kraków-Janowice - 27-29 09. 2010 (conference papers).

Książek M.A., Ziemiański D., Basista Z., Tarnowski J. 2008, Models of human - operator as a pushforce regulator in hand tool system, The 2 nd American Conference on Human Vibration, Chicago, 03-07 June 2008, Proc. 